\title{
Pengaruh Pemberian Silase Komplit Berbahan Dasar Hijauan yang Berbeda terhadap Kandungan Glukosa Darah dan Urea Darah Kambing Kacang
}

\author{
Jaimito Fahik ${ }^{\mathrm{a}}$ dan Paulus Klau Tahuk ${ }^{\mathrm{b}}$ \\ ${ }^{a}$ Fakultas Pertanian, Universitas Timor, Kefamenanu, TTU-NTT, Indonesia, email: jaimitofahik06@gmail.com \\ ${ }^{b}$ Fakultas Pertanian, Universitas Timor, Kefamenanu, TTU - NTT, Indonesia, email: paulklau@yahoo.co.id
}

\section{Article Info}

Article history:

Received 16 Desember 2019

Received in revised form 25 Desember 2019

Accepted 14 Januari 2020

$D O I$

https://doi.org/10.32938/ja.v5i1.927

\section{Keywords:}

Silase komplit

Glukosa darah

Urea darah

Kambing kacang

\section{Abstrak}

Pemanfaatan pakan ternak kambing dapat dilihat dalam penyerapan nutrisi pakan yang ada di dalam darah. Pakan yang dikomsumsi akan diserap ke dalam darah untuk dialirkan ke seluruh tubuh. Glukosa darah digunakan sebagai indikator aktivitas metabolisme ener gi dan pemanfaatan karbohidrat pada pakan, sedangkan Urea darah merupakan senyawa yang terdapat di dalam darah yang berasal dari ammonia hasil dari metabolisme protein. Tujuan dari penelitian ini adalah untuk melihat pengaruh pemberian silase komplit berbahan dasar hijauan yang berbeda terhadap kandungan glukosa darah dan urea darah kambing kacang jantan. Variabel yang diukur dalam penelitian ini adalah glukosa darah dan urea darah kambing kacang jantan. Bahan yang akan digunakan adalah hijauan sorgum, lamtoro, rumput alam, rumput raja, tepung jagung dan pollard serta bahan-bahan dalam analisis laboratorium. Metode yang digunakan adalah Rancangan Acak Lengkap dengan variasi perlakuan sebagai berikut: T1 $=$ Rumput Alam 45\% + Lamtoro 20\% + Jagung $25 \%+$ Bran Pollard $10 \%, \mathrm{~T} 2=$ Sorgum $45 \%+$ Lamtoro 20\%+ Jagung 25\% + Bran Pollard 10\%, T3= Rumput raja 45\% + Lamtoro 20\% + Jagung 25\% + Bran Pollard $10 \%$. Hasil penelitian menunjukkan bahwa perlakuan berpengaruh tidak nyata terhadap kandungan glukosa dan urea darah kambing kacang. Disimpulkan bahwa kadar glukosa darah dan urea darah ternak kambing kacang jantan yang diberikan silase komplit berbahan dasar rumput alam (T1), hijauan sorgum (T2), rumput raja (T3) memberikan pengaruh yang tidak nyata. Glukosa darah dan urea darah yang dihasilkan masih dalam kisaran normal.

\section{Pendahuluan}

Kambing Kacang merupakan salah satu jenis ternak ruminansia kecil yang sangat populer di kalangan petani di Indonesia. Tubuh kambing kacang kecil dan relatif lebih pendek, jantan maupun betina bertanduk, leher pendek dan punggung meninggi, warna bulu hitam, cokelat, merah, atau belang yang merupakan kombinasi dari warna yang ada pada kambing tersebut, kepala ringan dan kecil, telinga pendek dan tegak lurus mengarah keatas depan (Suparman, 2007). Kambing kacang memiliki daya adaptasi yang tinggi terhadap kondis alam setempat dan kemampuan reproduksinya dapat digolongkan sangat tingg (Sumardianto et al., 2013). Tingkat kesuburan kambing kacang sangat tingg dengan kemampuan hidup dari lahir sampai sapih sebesar 79,40\% (Pamungkas et al., 2008).

Pengembangan usaha peternakan kambing kacang saat ini merupakan salah satu usaha yang dilakukan oleh masyarakat di Kabupaten Timor Tengah Utara (TTU) dalam rangka menopang perekonomian keluarga. Usaha peternakan yang dilaksanakan umumnya masih bersifat skala kecil sehingga belum memberikan pengaruh yang signifikan terhadap perubahan ekonomi masyarakat Populasi ternak kambing diwilayah Kabupaten TTU saat ini memperlihatkan tingkat produktivitas yang cukup, hal ini dapat dilihat data pada tahun 2015 sebanyak 410,17 ekor dan tahun 2016 sebanyak 446,55 ekor (BPS Kab. TTU, 2016)

Pengembangan usaha peternakan kambing kacang banyak dipengaruh oleh berbagai faktor salah satunya ketersediaan pakan baik dari sisi kualitas maupun kuantitas dan dalam aplikasinya dibutuhkan penerapan sesuai dengan kebutuhan ternak. Hijauan merupakan makanan pokok ternak ruminansia namun demikian hijauan memiliki kendala dalam ketersediaannya. Dimana musim kemarau hijauan sangat minim dalam kualitas dan kuantitasnya, sedangkan pada musim hujan sangat melimpah. Guna mengatasi hal tersebut, salah satu upaya yang dapat dilakukan adalah dengan memanfaatkan kelimpahan hijauan saa musim hujan untuk digunakan pada saat musim paceklik. Hal ini dapat di lakukan dengan teknologi silase. Silase adalah hasil pengawetan hijauan dalam kondisi segar yang disimpan dalam silo pada kondisi anaerob. Lamanya fermentasi silase biasanya selama 21 hari dan dapat disimpan berbulan-bulan bahkan bertahuntahun untuk mengatasi kekurangan hijauan makanan ternak ruminansia di musim kemarau. Faktor yang dapat mempengaruhi kualitas silase diantaranya adalah bahan dasar penyusunnya dan aditif yang digunakan.

Pemanfaatan pakan ternak kambing dapat dilihat dalam penyerapan nutris pakan yang ada di dalam darah. Pakan yang dikonsumsi akan diserap ke dalam darah untuk dialirkan ke seluruh tubuh. Glukosa darah digunakan sebaga indikator aktivitas metabolisme energi dan pemanfaatan karbohidrat pada pakan, sedangkan Urea darah merupakan senyawa yang terdapat di dalam darah yang berasal dari ammonia hasil dari metabolisme protein (Mahesti, 2009). Tujuan dari penelitian ini adalah untuk melihat pengaruh pemberian silase kompli berbahan dasar hijauan yang berbeda terhadap kandungan glukosa darah dan urea darah kambing kacang jantan.

\section{Metode}

\subsection{Waktu dan Lokasi Penelitian}

Penelitian ini dilaksanakan pada bulan Maret-Juli 2019 di Fakultas Pertanian Universitas Timor, sedangkan analisis sampel darah ternak kambing dilakukan di Laboratorium Fakultas Peternakan Universitas Nusa Cendana.

\subsection{Materi Penelitian}

\subsubsection{Ternak}

Ternak yang digunakan adalah kambing kacang jantan berumur 9-12 bulan sejumlah 12 ekor dengan berat badan awal 8-11 kg

\subsubsection{Alat dan Bahan}

Alat yang digunakan adalah timbangan gantung kapasitas $40 \mathrm{~kg}$ untuk menimbang pakan dan ternak, timbangan digital, tabung darah yang berisikan lithium heparin, jarum hisap, mikroskop, counting chamber, spektrofotometri, arang, mesin potong rumput, ember, terpal, sapu lidi, gergaji, hamar, paku, drum plastik kapasitas 150 liter sebagai silo, bulpen, buku tulis dan spidol. Sedangkan bahan yang digunakan adalah hijauan sorgum, rumput alam, rumput raja, lamtoro, tepung jagung dan bran pollard serta bahan-bahan dalam analisis laboratorium.

\subsubsection{Kandang}

Kandang yang digunakan adalah kandang individu berbentuk panggung dengan jarak lantai kandang dari tanah adalah 50-100 cm. Kandang terdiri atas 12 petak dengan ukuran panjang $1,5 \mathrm{~m}$, lebar $50 \mathrm{~cm}$, dan tinggi $1 \mathrm{~m}$. Tempa pakan hijauan menempel pada sisi depan dan terbuat dari bambu berbentuk persegipanjang. Tempat air minum dengan ukuran 5 liter disediakan dalam kandang. Dinding dan lantai kandang terbuat dari bilah-bilah bambu dengan tujuan untuk memudahkan pembersihan kandang serta atap kandang dari seng.

\subsection{Rancangan Percobaan}

Metode penelitian yang digunakan dalam penelitian ini adalah Rancangan Acak Lengkap (RAL) yang terdiri dari 3 perlakuan dan 4 ulangan. Perlakuan yang diberikan adalah sebagai berikut

T1 : Rumput Alam 45\% + Lamtoro 20\% + Jagung 25\% + Bran pollard 10\%

T2 : Sorgum $45 \%+$ Lamtoro $20 \%+$ Jagung $25 \%+$ Bran pollard $10 \%$

T3 : Rumput Raja 45\% + Lamtoro 20\% + Jagung 25\% + Bran pollard 10\%.

Tabel 1. Komposisi Kimia Silase Komplit

\begin{tabular}{|c|c|c|c|}
\hline Bahan Hijauan & T1 & $\mathrm{T} 2$ & T3 \\
\hline $\mathrm{BK}(\%)$ & 94,89 & 93,75 & 94,41 \\
\hline $\mathrm{BO}(\%)$ & 86,77 & 88,14 & 84,84 \\
\hline PK (\%) & 9,94 & 13,81 & 11,11 \\
\hline LK $(\%)$ & 5,23 & 7,29 & 6,98 \\
\hline SK $(\%)$ & 27,26 & 14,86 & 22,05 \\
\hline $\mathrm{CHO}(\% \mathrm{BK})$ & 71,59 & 67,03 & 66,74 \\
\hline BETN (\%BK) & 44,33 & 51,91 & 44,69 \\
\hline $\mathrm{GE}^{* *}-(\mathrm{Mj} / \mathrm{kgBK})$ & 16,58 & 17,43 & 16,62 \\
\hline$-(\mathrm{Mj} / \mathrm{kgBK})$ & 3947,92 & 4151,22 & 3957,66 \\
\hline $\mathrm{EM}^{* *}(\mathrm{Kkal} / \mathrm{kg} \mathrm{BK})$ & 2731,39 & 3382,52 & 2940,45 \\
\hline
\end{tabular}

Hasil Analisis Laboratorium Kimia Pakan Fakultas Peternakan Universitas Nusa Cendana (2019)

\subsection{ProsedurPenelitian \\ 2.4.1 Masa Persiapan}

Dalam masa persiapan ini hal yang dilakukan adalah menyiapkan kandang dan persiapan lainnya termasuk persiapan pembuatan silase komplit. Kandang kambing milik program studi peternakan, Fakultas Pertanian Unimor, direhab dengan membuat 12 petak kandang menggunakan bilah bambu. Setelah kandang direhab selanjutnya dilakukan pemotongan sorgum, lamtoro, rumput alam, rumput raja serta persiapan tepung jagung dan brand pollard kemudian dibuat silase komplit.

\subsubsection{Kandang dan perlengkapan kandang}

Kandang dibuat tipe individu, dilengkapi tempat makan dengan ukuran panjang $60 \mathrm{~cm}$, lebar $30 \mathrm{~cm}$ (dibuat dari bilah bambu dan papan) dan tempat minum (dibuat dari ember plastik). Kandang berbentuk panggung dengan ukuran lebar kandang 2,30 m, dan dalam kandang dibagi menjadi 2 bagian yakni sebelah kiri terdapat 6 petak dan kanan 6 petak yang letaknya saling berhadapan. 


\subsubsection{Pembuatan silase}

Bahan dasar hijauan yang akan digunakan dalam pembuatan silase adalah sorgum, rumput raja dan rumput alam. Hijauan sorgum tersebut dipanen awal masa berbunga setelah tanam, kemudian dicacah dengan ukuran panjang sekitar $\pm 2-3 \mathrm{~cm}$. Cacahan sorgum/rumput raja/rumput alam dicampur dengan lamtoro yang telah dicacah dengan ukuran yang sama. Kemudian menimbang bahan tambahan sesuai perlakuan masing-masing, dan taburkan secara merata di atas cacahan hijauan sorgum/rumput raja/rumput alam dan lamtoro tersebut. Aduk cacahan sorgum/rumput raja/rumput alamdan bahan-bahan tambahan berupa tepung jagung dan branpollard sampai tercampur merata dan masukan secara bertahap campuran tersebut kedalam silo fermentor (drum plastik), padatkan setiap kali memasukan campuran cacahan dan bahan aditif untuk mengeluarkan oksigen sebanyak mungkin. Terakhir silo yang telah terisi silase disimpan dalam ruangan pada suhu kamar selama 21 hari.

\subsubsection{Prosedur pemberian pakan dan air minum}

Setelah 21 hari silo dibuka dan diangin-anginkan, kemudian melakukan adaptasi ke ternak selama 2 minggu. Setelah masa adaptasi maka silase diaplikasikan ke ternak perlakuan 2 kali dalam sehari yakni pagi hari pukul 08.00 dan sore hari pukul 16.00 , sebanyak $10 \%$ dari berat badan/ekor. Air minum diberikan secara ad libitum yakni disediakan secara terus menerus pada ember dan jergen plastik yang diletakan disamping tempat makan.

\subsubsection{Prosedur Koleksi Darah}

Darah di ambil pada minggu terakhir penelitian, melalui vena junggularis, menggunakan jarum serta tabung darah ukuran $3 \mathrm{ml}$ yang berisi lithium heparin. Pengambilan darah setiap kambing sebanyak 4 kali/ekor, dengan perbedaan waktu/jam yaitu: 0 jam sebelum diberi makan, selanjutnya 2 jam, 4 jam dan 6 jam setelah diberi makan. Darah yang ditampung pada tabung, kemudian disimpan dalam termos es untuk selanjutnya dilakukan analisis darah di Laboratorium Fapet Undana.

\subsection{Variable Penelitian}

Variabel yang diteliti adalah kadar glukosa dan urea darah yang dianalisis menggunakan metode spektrofotometri

\subsection{Analisis Data}

Data yang diperoleh ditabulasi kemudian dianalisis mengikuti prosedur Analysis of Variance (ANOVA) sedangkan untuk rancangan acak lengkap (RAL)menggunakan SPSS versi 19.0.

\section{Hasil dan Pembahasan}

3.1 Pengaruh Perlakuan Terhadap Kandungan Glukosa Darah Ternak

\section{Kambing Kacang Jantan}

Glukosa darah berasal dari pencernaan karbohidrat pakan, senyawa glukogenetik yang mengalami glukoneogenesis (pembentukan glukosa dari senyawa non karbohidrat, misalnya protein dan lemak) dan glikogen hati yang mengalami glikogenesis (pemecahan glikogen menjadi glukosa) (McDonald et al., 2010). Hasil analisis laboratorium terhadap kandungan glukosa darah ternak kambing kacang jantan yang di berikan pakan silase komplit berbahan dasarhijauan yang berbedadapat di lihat pada Tabel 2 .

Tabel 2. Kandungan Glukosa Darah ternak Kambing Kacang Jantan Percobaan

\begin{tabular}{cccc}
\hline \multirow{2}{*}{ Glukosa Darah (mg/dL) } & \multicolumn{3}{c}{ Perlakuan } \\
\cline { 2 - 4 } & $\mathrm{T} 1$ & $\mathrm{~T} 2$ & $\mathrm{~T} 3$ \\
\hline 0 Jam & $82,603 \pm 5,656$ & $86,878 \pm 6,986$ & $85,418 \pm 3,300$ \\
2 Jam & $86,310 \pm 4,606$ & $81,295 \pm 6,351$ & $87,983 \pm 2,979$ \\
4 Jam & $90,328 \pm 8,777$ & $88,540 \pm 5,157$ & $89,565 \pm 5,308$ \\
6 Jam & $85,688 \pm 3,989$ & $82,665 \pm 5,882$ & $82,933 \pm 2,461$ \\
\hline Rata-rata & $86,232 \pm 3,175$ & $84,845 \pm 3,423$ & $86,475 \pm 2,915$ \\
\hline
\end{tabular}

Pada Tabel 2 terlihatbahwa kadar glukosa darah kambing kacang jantan muda (umur 9-12 bulan) pada pemeliharaan intensif dengan pemberian pakan berupa silase komplit berbahan dasar hijauan yang berbeda masing-masing pada kisaran 0, 2, 4, 6jam untuk perlakuan T1 adalah 82,603; 86,310; 90,328; dan $85,688 \mathrm{mg} / \mathrm{dl}$ atau rata-rata sebesar $86,232 \mathrm{mg} / \mathrm{dl}$. Untuk perlakuan T2 adalah 86 , $878 ; 81,295 ; 88,540$ dan $82,665 \mathrm{mg} / \mathrm{dl}$ atau rata-rata sebesar $84,845 \mathrm{mg} / \mathrm{dl}$; dan untuk perlakuan T3 adalah sebesar 85,418; 87,983; 89, 566; dan 82, $933 \mathrm{mg} / \mathrm{dl}$ atau rata-rata $86,475 \mathrm{mg} / \mathrm{dl}$. Kadar glukosa darah tiap ternak kambing jantan pada masing-masing perlakuan dalam penelitian ini cukup berfluktuasi. Rata-rata glukosa darah dari masing-masing perlakuan menunjukkan konsentrasi yang tinggi dan cukup berbeda pada 0 jam (sebelum pemberian pakan) dan mencapai puncak tertinggi setelah 4 jam pemberian pakan, yang selanjutnya menurun pada 6 jam setelah pemberian pakan.

Salah satu faktor yang mempengaruhi kadar glukosa darah adalah jumlah ransum yang dikonsumsi (Rahayu, 2017). Peningkatan glukosa darah pada 0 jam sebelum pemberian pakan dan 2 jam hingga 4 jam setelah konsumsi pakan diduga karena ada kaitannya dengan lama tinggal hijauan dalam rumen, dimana ternak yang mengkonsumsi pakan dengan jenis hijauan maka masa tinggal pakan dalam rumen lebih lama karena proses pencernaan oleh mikroorganisme lebih lambat. Konsentrasi glukosa darah yangmenurun pada 6 jam setelah makan didugaberkaitan dengan sifat glukosa itu sendiri dimana glukosa merupakan salah satu nutrient dalam darah yang konsentrasinya mudah berubah dari waktu ke waktu. Dengan demikian kadar glukosa sangat ditentukan oleh waktu pengambilan darah (Riis, 1983). Hasil penelitian ini menunjukkan bahwa ternak kambing kacang jantan muda yang mengkonsumsi silase komplit berbahan dasar hijauan yang berbeda mampu meningkatkan kadar glukosa dalam darah baik untuk perlakuan (T1; T2 dan T3) dan masih berada dalam kisaran normal Menurut Mitruka et al., (1977) kisaran normal kadar glukosa darah pada ternak ruminansia bervariasi antara $43-100 \mathrm{mg} / \mathrm{dl}$. Normalnya kadar glukosa darah ini selain karena faktor energi yang disuplai dari pakan yang dikonsumsi, juga karena adanya mekanis mekontrol oleh hormon insulin.

Glukosa darah ternak ruminansia tidak hanya berasal dari sakarida pakan tetapi dari volatile fatty acid (VFA) yang berasal dari pencernaan serat kasar atau karbohidrat difermentasi oleh mikroba rumen menjadi VFA (Manu, 2007 dalam Tahuk et al., 2008), dikatakan lebih lanjut bahwa 40-60\% glukosa darah berasal dari propionat, $20 \%$ dari protein dan sisanya berasal dari VFA rantai cabang, asam laktat dan gliserol. Asam amino dapat menyumbang glukosa sebanyak $11-$ $30 \%$ dari total glukosa dimana substrat yang paling penting adalah alanin, glutamate dan aspartat. Hormon juga dapat mempengaruhi kadar glukosa darah. Pengaturan konsentrasi glukosa darah dipengaruhi oleh hormon insulin dan glukagon yang disekresikan dalam pankreas dan selanjutnya ke dalam darah. Insulin merupakan hormon peptida yang disekresikan oleh sel beta pankreas. Bira (2016) menyatakan bahwa dalam proses metabolisme karbohidrat hasilnya akan disimpan dalam bentuk glikogen yang merupakan karbohidrat penyimpan energi yang terdiri dari unit-unit glukosa.

Rata-rata kadar glukosa darah dalampenelitianini yang terbaik (tinggi) ditunjukkan oleh ternak yang mendapat perlakuan $\mathrm{T} 3$ dengan rata-rata kadar glukosa darah sebesar $86,475 \pm 2,915 \mathrm{mg} / \mathrm{dl}$, yang berarti lebih tinggi bila dibandingkan dengan laporan hasil penelitian Tahuk et al., (2008), pada kambing bligon jantan dengan kadar glukosa darah $73,80 \pm 11,10 \mathrm{mg} / \mathrm{dl}$, serta pada penelitian Faisal et al. (2017) yang meneliti pada ternak kambing boer dengan kadar glukosa $68 \pm 6,5 \mathrm{mg} / \mathrm{dl}$. Perbedaan hasil penelitian ini dengan penelitian lain diduga lebih pada perbedaan tempat dan pakan yang diujicobakan. Apabila pakan yang diberikan telah sesuai kebutuhan akan menghasilkan kandungan metabolik yang normal namun apabila pakan yang diberikan kurang maka nilai metabolik darah akan rendah (Ogata et al., 2010).

\subsection{Pengaruh Perlakuan Terhadap Kandungan Urea Darah Ternak Kambing Kacang Jantan}

Urea darah adalah hasil akhir dari proses metabolisme protein dalam tubuh ternak ruminansia yang tidak dimanfaatkan oleh tubuh sehingga di keluarkan lewat urin (Tillman et al., 1991). Hasil analisis laboratorium terhadap kandungan urea darah ternak kambing kacang jantan yang di berikan pakan silase komplit berbahan dasarhijauan yang berbeda dapat di lihat pada Tabel 3 .

Tabel 3.Kandungan Urea Darah ternak Kambing Kacang Jantan Percobaan

\begin{tabular}{cccc}
\hline \multirow{2}{*}{ Urea Darah $(\mathrm{mg} / \mathrm{dL})$} & \multicolumn{3}{c}{ Perlakuan } \\
\cline { 2 - 4 } & $\mathrm{T} 1$ & $\mathrm{~T} 2$ & $\mathrm{~T} 3$ \\
\hline 0 Jam & $46,295 \pm 3,861$ & $45,190 \pm 6,099$ & $46.318 \pm 1,330$ \\
2 Jam & $50,488 \pm 2,960$ & $50,640 \pm 1,048$ & $51,170 \pm 1,270$ \\
4 Jam & $55,130 \pm 5,014$ & $56,865 \pm 3,873$ & $51,978 \pm 2,846$ \\
6 Jam & $55,108 \pm 3,076$ & $50,093 \pm 2,465$ & $51,005 \pm 4,618$ \\
\hline Rata-rata & $51,755 \pm 4,245$ & $50,652 \pm 4,788$ & $50,118 \pm 2,569$ \\
\hline
\end{tabular}

Pada Tabel 3 terlihatbahwa kandungan kadar urea darah kambing jantan muda pada pemeliharaan dengan pemberian pakan berupa silase komplit berbahan dasar hijauan yang berbeda masing-masing pada kisaran $0,2,4,6 \mathrm{jam}$ untuk perlakuan T1 adalah 46,295; 50, 488; 55,130; dan 55,108mg/dl atau ratarata sebesar $51,755 \mathrm{mg} / \mathrm{dl}$. Untuk perlakuan T2 adalah 45, 190; 50,640; 56, 865 dan $50,093 \mathrm{mg} / \mathrm{dl}$ atau rata-rata sebesar $50,652 \mathrm{mg} / \mathrm{dl}$; dan untuk perlakuan T3 adalah sebesar 46,318; 51, 170;51,978; dan 51, $005 \mathrm{mg} / \mathrm{dl}$ atau rata-rata 50,118 $\mathrm{mg} /$ dl. Sebagaimana pada kadar glukosa darah di atas, untuk kadar urea darah pun tiap ternak kambing kacang jantan pada masing-masing perlakuan dalam penelitian ini cukup berfluktuasi. Rata-rata urea darah dari masing-masing perlakuan menunjukkan konsentrasi tinggi pada 0 jam (sebelum pemberian pakan) dan mencapai puncak tertinggi setelah 4 jam pemberian pakan, yang selanjutnya menurun pada saat 6 jam setelah pemberian pakan kandungan urea darah juga relatif sama karena proses pencernaan konsentrat dalam rumen perlahan-lahan menurun. Arifin dan Zulfanita (2012), menyatakan bahwa kisaran kadar urea darah yang normal pada kambing adalah antara 26,6 dan 56,7mg/dl. Menurut Tahuk et al. (2008), kisaran kadar urea darah ternak kambing bligon jantan pada penggemukan level protein pakan berbeda adalah antara 30,00 dan $55,00 \mathrm{mg} / \mathrm{dl}$. Tingginya kadar urea darah diduga berkaitan erat dengan banyaknya senyawa yang mengandung nitrogen dalam bahan pakan yang dikonsumsi oleh ternak serta cekaman panas yang terjadi saat penelitian berlangsung. Hal ini sesuai dengan pendapat Riis (1983), yangmenyatakan bahwa dalam darah dipengaruhi oleh pakan karena sebagian besar urea diperoleh dari penguraian protein yang berasal dari pakan. Pada ternak yang mempunyai asupan protein tinggi, sebagian besar protein tersebut mengalami fermentasi di rumen, dapat menyebabkan peningkatan kadar urea dalam darah di atas rentang normal. Penurunan kadarurea darah pada 6 jam setelah pemberian pakan diduga 
karena ternak kambing jantan percobaan mengalami cekaman panas atau stres panas dan menyebabkan ternak kambing jantan reabsorbsi yang berlebih pada kadar urea dari darah ke rumen sebagai suatu kompensasi dari penurunan amonia karena penurunan konsumsi bahan kering dan penurunan kecernaan nitrogen. Senyawa mengandung nitrogen yang dapat dimanfaatkan oleh ternak ruminansia untuk proses pertumbuhan dan produksinya, terdiri atas protein dan nonprotein nitrogen (NPN). Sebagian protein (protein by pass) tidak mengalami fermentasi di dalam rumen akan tetapi langsung diserap di usus untuk digunakan sebagai protein pembentuk jaringan tubuh, dan sebagian lagi mengalami fermentasi didalam rumen (Mc Donald, 2002).

Rata-rata kadar urea darah dalam penelitian ini yang terbaik (rendah) ditunjukkan oleh ternak yang mendapat perlakuan R3 dengan rata-rata kadar urea darah sebesar 50,118 $\pm 2,569 \mathrm{mg} / \mathrm{dl}$. Bila di bandingkan dengan penelitian Tahuk et al. (2008), kisaran kadar urea darah ternak kambing bligon jantan pada penggemukan level protein pakan berbeda adalah antara 30,00-55,00 mg/dl. Menurut Mitruka et al. (1981) dikutip Tahuk et al. (2008), kadar urea darah yang normal pada ternak kambing adalah 13-44 mg/dl. Soeparno (2005), menyatakan bahwa protein yang masuk kedalam tubuh akan mengalami tiga kemungkinan yaitu dicerna oleh mikroba rumen, mengalami degradasi, dan diserap melalui dinding rumen lalu dibawah menuju hati, diubah menjadi urea dan kemungkinan lain yaitu protein melalui rumen tanpa mengalami degradasi. Pada ternak muda protein yang diabsorbsi dimanfaatkan oleh tubuh ternak untuk pertumbuhan, mengganti sel-sel yang rusak dan pada kondisi tertentu akan diubah menjadi energi.

\section{Simpulan}

Disimpulkan bahwa kadar glukosa darah dan urea darah ternak kambing kacang jantan yang diberikan silase komplit berbahan dasar rumput alam (T1), hijauan sorgum (T2), rumput raja (T3) memberikan pengaruh yang tidak nyata. Glukosa darah dan urea darah yang dihasilkan masih berada pada kisaran normal.

\section{Pustaka}

Arifin, H.D. dan Zulfanita. 2012. Amonia rumen dan urea darah kambing Jawarandu pengaruh pemberian daun papaya. Surya Agritama, 1 (1): $38-$ 47.

Bira, G.F. 2016. Profil Darah Sapi Bali Yang Mendapat Konsentrat Berbahan Semak Bunga Putih (Chromolaena odorata) Dengan Level Yang Berbeda. Journal of Animal Science, 1 (3) : 30-31.

BPS Kab. TTU. 2016. Kabupaten TTU dalam Angka Tahun 2016.

Faisal, F., A. Rochana dan K.A. Kamil. 2017. Kajian Kandungan Kimia Darah Dan Pertambahan Bobot Badan Domba Garut Betina Lepas Sapih Dengan Imbangan Protein Dan Energi Yang Berbeda. Jurnal Ilmu Ternak, 17 (2) : 92-96.

Mahesti, G, 2009. Pemanfaatan protein pada Domba lokal Jantan dengan Bobot badan dan Asas Pemberian Pakan yang Berbeda. Tesis. Program Studi Magister Ilmu Ternak Program Pasca Sarjana Fakultas Peternakan Universitas Diponegoro, Semarang.

Mc Donald P, Edwards RA, Greenhalgh JFD, Morgan CA, Sinclair LA, Wilkinson RG. 2010. Animal Nutrition. 7th ed. New York. John Wiley Inc. Hlm. 318-320.

Mc Donald, P., R.A. Edwards, J.F.D. Greenhalg and C.A. Morgan. 2002. Animal Nutrition. $6^{\text {th }}$ Ed. Ashford Color Pr., Gosport.

Mitruka, B.M. and Rawnsley, H.M. and Vadehra, B.V., 1977. Clinical biochemical and hematological reverence values in normal experimental animals and normal humans. $2^{\text {nd }}$ ed. Year Book Medical Publishing Inc., New York.

Ogata, Y., M. K. Alam, Y. Sako, M. Al-Mamun and H. Sano. 2010. Intermediary Metabolism of Plasma Acetic Acid, Glucose and Protein in Sheep Fed a Rice Straw-based Diet. Iwate University. Morioko, Japan.

Pamungkas, F. A., A. Batubara., M. Doloksaribu dan E. Sihite. 2008. Petunjuk Teknis Potensi Beberapa Plasma Nutfah Kambing Indonesia. Loka Penelitian kambing potong sei putih, pusat penelitian dan pengembangan peternakan, Sumatera Utara.

Rahayu, S., M. Yamin., C. Sumantri dan D. A. Astuti. 2017. Profil Hematologi dan Status Metabolit Darah Domba Garut yang Diberi Pakan Limbah Tauge pada Pagi atau Sore Hari. Jurnal Veteriner, 18 (1) : 38-45.

Riis, P. M. 1983. Dynamic Biochemistry of Animal Production. Elsevier, New York. [Diakses pada tanggal 16 September 2019]

Soeparno. 2005. Ilmu dan Teknologi Daging. Gadjah Mada University. Yogyakarta. $1-40 ; 283$.

Suparman, 2007 Beternak Kambing. Azka Press. Jakarta.

Tahuk, P. K., E. Baliarta dan H. Hartadi. 2008. Kinerja Kambing bligon pada penggemukan dengan level protein pakan berbeda. Buletin peternakan, 32 (2) : 121-135.

Tillman, A.D., H. Hartadi, S. Reksohadiprodjo, S. Prawirokusumo dan S. Lebdosoekojo. 1991. Ilmu Makanan Ternak Dasar. Gadjah Mada University Press, Yogyakarta.

Sumardianto, T. A. P., E. Purbowati dan Masykuri. 2013. Karakteristik Karkas Kambing Kacang, Kambing Peranakan Ettawa, DAN Kambing Kejobong Jantan Pada Umur Satu Tahun. Animal Agriculture journal, 2 (1) : 175182. 